K.I. Zhevachevskaya

\title{
COMMUNICATIVE STRATEGIES OF APPRECIATION LETTERS SENT TO AMERICAN VOLUNTEERS AND THEIR LINGUISTIC MANIFESTATION
}

(C) Zhevachevskaya Kristina Igorevna - postgraduate student, Faculty of Philology, Lomonosov Moscow State University, 1, Leninskie Gory, Moscow, 119991, Russian Federation.

E-mail: kzhevachevskaya@mail.ru. ORCID: https://orcid.org/0000-0002-8439-4216

\section{ABSTRACT}

The article is devoted to the study of communicative strategies that are used in the texts of appreciation letters sent to volunteers and their linguistic manifestation in American English. The material for the research is borrowed from the websites of various American volunteer organizations.

The following methods are used in the research: the descriptive method including classification, systematization and generalization, and that of contextual analysis. The author singles out linguistic tactics used by representatives of volunteer centers to achieve the communicative aim.

The article shows that the main linguistic tactic in this type of business correspondence is that of appreciation, which is realized with the help of the verb "to thank" and other cognate words. Moreover, a number of additional communicative aims, strategies and linguistic expressions are identified.

Key words: volunteer, volunteer movement in the USA, communication, communicative strategies, American English.

Citation. Zhevachevskaya K.I. Communicative strategies of appreciation letters sent to American volunteers and their linguistic manifestation. Vestnik Samarskogo universiteta. Istoriia, pedagogika, filologiia [Vestnik of Samara University. History, pedagogics, philology], 2019, Vol. 25, no. 1, pp. 136-141. DOI: http:// doi.org/10.18287/2542-0445-2019-25-1-136-141 [in English].

This is an open access article distributed under the Creative Commons Attribution License Which permits unrestricted use, distribution, and reproduction in any medium, provided the original work is properly cited. (CC BY 4.0) 
Zhevachevskaya K.I.

Communicative strategies of appreciation letters sent to American volunteers and their linguistic manifestation

К.И. Жевачевская

\section{РЕАЛИЗАЦИЯ КОММУНИКАТИВНЫХ СТРАТЕГИЙ В БЛАГОДАРСТВЕННЫХ ПИСЬМАХ АМЕРИКАНСКИМ ВОЛОНТЕРАМ}

(C) Жевачевская Кристина Игоревна - аспирант филологического факультета, Московский государственный университет имени М.В. Ломоносова, 119991, Российская Федерация, г. Москва, Ленинские горы, 1. E-mail: kzhevachevskaya@mail.ru. ORCID: https://orcid.org/0000-0002-8439-4216

\section{АННОТАЦИЯ}

Данная статья посвящена исследованию коммуникативных стратегий, используемых в текстах благодарственных писем, высылаемых членам волонтерского движения, и языковых средств их реализации. Автором проанализирован корпус текстов американского варианта английского языка. Материалом исследования служила информация с сайтов американских волонтерских центров.

В работе использовались следующие методы: описательный, включающий классификацию, систематизацию и обобщение материала, и метод контекстуального анализа. В процессе исследования выделялись языковые тактики, которые применяются представителями волонтерских центров для реализации поставленной задачи.

По заключению автора статьи, превалирующей тактикой в этом типе деловой корреспонденции является тактика благодарности, которая осуществляется посредством глагола to thank («благодарить») и однокоренных слов. Кроме того, выделяется ряд дополнительных речевых целей, их стратегии и языковые способы реализации.

Ключевые слова: волонтер, волонтерское движение в США, коммуникация, коммуникативные стратегии, американский английский.

Цитирование. Zhevachevskaya K.I. Communicative strategies of appreciation letters sent to American volunteers and their linguistic manifestation // Вестник Самарского университета. История, педагогика, филология. 2019. Т. 25. № 1. C. 136-141. DOI: http://doi.org/10.18287/2542-0445-2019-25-1$136-141$.

Modern linguistics is characterized by the increasing interest in the process of communication. The scholars' attention is directed towards such notions as linguistic manipulation, communicative strategies and tactics. The term "communication" has a number of definitions depending on the field of knowledge, including social science, psychology, philology, politics, cultural anthropology and others.

"Linguistic encyclopedic dictionary" gives the following definition of the above-mentioned term "a specific form of people's cooperation in the process of their cognitive and work activity" (Linguistic encyclopedic dictionary). In order to achieve the goals of the communicative act it is necessary to adopt and follow effective strategies, which are studied by many philologists. For example, the Russian Professor Sternin I. A. defines the term "communicative strategy" in the following way: "common stereotypes of planning linguistic manipulation depending on communication conditions and personalities, determined by the communicative goal" [Sternin 2006, p. 14].

The aim of the present research is to outline and explore the main communicative strategies used in appreciation letters that are sent to volunteers in the USA. In order to achieve this goal it is necessary to analyze the corpus of this kind of business correspondence, to outline communicative aims, to single out realized strategies and to find out what their linguistic manifestation is. The material for the research is borrowed from websites of various American volunteer centers.

Volunteers are an essential part of non-profit organizations all over the world, that is why it is very important to find ways in order to show appreciation for the careful work done and to motivate them to take part in the further activity of a firm. There are a number of means to do that: for example, by providing volunteers with gifts such as cinema or theatre tickets, with tickets to travel by public transport, etc. In addition to these above-mentioned ways heads of volunteer centers frequently send volunteers the so-called letters of thanks, which are regarded as part of business correspondence, after participating in various events.

A thank-you letter meets the requirements of business letter style in respect of the content and the document layout. In the article "Grammar in the Registers of Business English: from Function to Form” Professor Nazarova T. B. singles out the following crucial components: "stating the purpose", where the author formulates the objective of a letter, "the main message of a letter" - the body of correspondence, "closing remarks" - the final part, which is full of clichés [Nazarova, Tolstova 2006, pp. 190-191]. 
One of the main communicative goals of thankyou letters is to express gratitude to those people who spend time, energy and give knowledge helping others. It is of great importance to point out that their work and contribution to the project where they are involved are deeply appreciated. These steps conduce to effective cooperation between members of volunteer centers and volunteers.

Due to the fact that this kind of correspondence is aimed at strengthening the volunteer's impression of experience, to evoke his or her warm feeling about the participation in the movement, the only strategy that is frequently used by the authors is the strategy of influence on the addressee through the following emotional tactics: the phatic tactic, the tactic of appreciation, that of compliment, of consolidation, of improving the relationship.

It should be noted that one of the best ways to implement the above-mentioned tactics is to use frequently various connotative words with positive meanings. In the "Dictionary of linguistic terms" Professor O.S. Akhmanova defines the term "connotation" as "the additional meaning of a word, its accompanied semantic or stylistic nuances superimposed over signification, which serve to show expressive-emotionalevaluative overtones (translated by Zhevachevskaya K.) (The Dictionary of linguistic terms, p. 198).

In the works by Professor Zadornova V.Ya. inherent and adherent connotations are singled out: the former is a permanent characteristic of a linguistic unit, the latter is created by evocation and acquired in a certain context when linguistic units are combined in a specific way [Zadornova 1986]. In the following examples of the present article lexical units that have inherent connotations as part of their stylistic characteristics will be discussed in detail.

It is obvious that a great deal of attention to the notion of volunteerism and the role of volunteers is paid in the appreciation letter. The author clearly realizes the extent to which the activity of every member of volunteer movement and his/her participation in a project are of considerable significance. That is why the text of the analyzed type of business letters abounds in the lexical unit "role" and descriptive adjectives with positive meaning. For example, in the phrase below the adjective "critical" is the synonym to "very important":

"You are all playing a critical role in ending hunger and homelessness in Central New York".

The volunteer's mission may be emphasized implicitly - by using lexical units of different parts of speech with positive connotative meaning. By this means of impacting on the volunteer's state of mind the addresser of the appreciation letter tries to arouse strong emotion, to work up positive information perception, to evoke warm and pleasant memories connected with one's experience in the movement. To prove this statement the following examples from various appreciation letters may be adduced:

(1) "You are a wonderful community living out your passion and helping to create a world in which every human life is valued and health and human dignity are shared by all".
(2) "Each and every one of you brings something unique and invaluable to the Rescue Mission".

(3) "Thousands of Rescue Mission volunteers gave more than 108,000 hours of service! This is such a staggering number and really shows what a giving community we have!"

(4) "You are an important part of the Rescue Mission's life-changing work!"

In order to show that the above marked units have inherent connotative meaning we provide the reader with definitions of these lexical units borrowed from the Macmillan Dictionary for Advanced Learners.

Examples (1) and (2) include the usage of two verbs "to help" and "to bring" where the relentless pursuit of peace, safety and liberty forms the basis of their definitions: "to help" - "to make it easier to achieve something", "to bring" - "to be the cause of a state, situation, or feeling" (Macmillan).

The use of descriptive adjectives in examples (2) and (4) shows what a crucial, significant and valuable role a volunteer has in every project: "unique" - "very special, unusual, or good", "invaluable" - "extremely useful", "staggering" - "extremely surprising" (Macmillan). By using the latter adjective the author of the thank-you letter points out the amount of time that volunteers spend on this activity and considerable respect for their efforts. It should be noted that some of the above-mentioned definitions have adverbs of quantity and degree, which contribute to the effect of what is written.

The addresser's attitude towards volunteers' work and way of thinking is shown in the word combinations "a wonderful community" and "a giving community": the author points out the kindness and generosity of members in this movement.

There are a number of sources that explain main the rules of writing letters to volunteers. One of the principal requirements is to personalize the text by addressing the reader in order to build a strong relationship - the phatic tactic. It is achieved by using the phrase "Dear...". The appreciation letter may be addressed to a particular volunteer ("Dear Mr. Mendel", "Dear Ray") or to a volunteer group ("Dear Volunteers", "To our courageous and dedicated volunteers"). In the latter example adjectives with inherent positive connotations help the author to render his/her sincere gratitude to the addressees: "dedicated" - "working very hard at what they do because they care a lot about it" (Longman 2006, p. 409).

Moreover, the phatic tactic is used at the end of the appreciation letter in order to deepen the established relationship between members of the communicative act. The linguistic means used in this case is the cliché "sincerely", if the addresser knows the name of the addressee, and "all the best", "cordially".

Consequently, the phatic tactic is closely connected with that of improving the relationship. In the majority of cases the author of the analyzed type of business correspondence expresses explicitly that the fact of 
volunteers spending time and energy on various projects with no promise of compensation is not overlooked. To prove this statement the following examples from various appreciation letters are given below:

(1) "You" re such an important part of our organization, and I hope you know that".

(2) "I wanted to let you know what an outstanding job I think you"re doing with the children you work with".

(3) "I just want you to know that your work hasn"t gone unnoticed".

The use of descriptive adjectives with positive connotative meaning ("important", "unnoticed", "outstanding") helps to show volunteers that the author understands the importance and significance of their work. Moreover, in order to enhance the meaning and to add expressivity the demonstrative pronoun "such" is included in example (1).

The above-mentioned phrases from appreciation letters clearly demonstrate how the addresser's choice of words actively encourages the relationship between the volunteer and the representative of volunteer centers: the former realizes the value of their actions, which motivates them to engage further in this popular movement.

Another tactic that is inevitably implemented in thank-you letters and makes volunteers feel valued and respected is that of appreciation. It realizes one of the most important principles of every speech act - the politeness principle. This tactic is regarded as predominant in the analyzed type of business correspondence.

The major linguistic unit in the tactic of appreciation is the verb "to thank": "Thank you for your generosity and your continued support of PTA's mission"; "Thanks again for your support". It should be noted that sometimes the author adds adverbs of quantity and degree to produce a powerful effect and expresses gratitude for the work done: "Thank you so much!"

Moreover, representatives of volunteer centers use other cognate words, such as "thankful" and "thankfulness": "I want to express my thankfulness to all of our volunteers; "I am thankful for your acts kindness each day”.

Furthermore, the above-mentioned tactic is implemented with the help of other synonymic constructions, such as "to express gratitude" and "to be grateful for something": for example, "We are so grateful for all you do".

Another emotional tactic that is conducive to effective cooperation between members of volunteer centers and volunteers is that of compliment. The author of the appreciation letter not only makes sentences more expressive and emotional by providing lexical units with positive connotations, which can be addressed to any member of volunteer movement, but also individualizes the letter in order to endear volunteers to him/ her and to arouse powerful emotions.

By mentioning particular qualities in volunteers' characters, making value judgements about their business skills and appreciating the significance of their work, representatives of volunteer centers frequently use the possessive pronoun "your", which shows that this or that trait or the above-mentioned characteristics belong to or are connected with a particular person or people the author is writing to. The aim is to receive the required emotional response from the reader: "Thank you for your kindness and love"; "The community will remember your generosity of spirit"; "Thank you for your patience and respect".

The author of the appreciation letter may single out either personal qualities of a volunteer (1) or top-notch carrying-out of work (2) by showing what changes they have caused in the life of people or the community. The linguistic means of implementing this tactic are given in the following examples:

1.1. nouns with positive connotative meaning: "Thank you for your contribution to PTA's Reflections program"; "Thank you for your courage and conviction";

1.2. adjectives with positive connotative meaning: "We appreciate your invaluable business expertise»;

1.3. forms of gerund: "Thank you for seeing the need and responding; "Thank you for being the inspiration the world needs";

2.1. nouns with positive connotative meaning: "Your investment in the program will help provide an arts-rich learning experience";

2.2. adjectives with positive connotative meaning: "You took great care to see that members followed protocol in each situation";

2.3. the form of gerund: "Thank you for sharing your skills to help improve lives"; "Thank you for supporting student success with your school-community's PTA"; "Thank you for helping and organizing all the donations"; "You spent long hours on various projects, sacrificing your personal time for the greater good of our citizenry".

In order to show that the underlined words carry positive inherent connotations we provide the reader with a selective range of definitions from the Longman Dictionary of Contemporary English: "contribution" means "when you give money, time, help etc." (Longman 2009, p. 340), "conviction" - "a very strong belief or opinion" (Longman 2009, p. 344), "investment" "when you spend a large amount of time, energy, emotion etc. on something" (Longman 2009, p. 857), "to share" "to let someone have and use something that belongs to you" (Longman 2009, p. 1509), "to sacrifice" - "when you decide not to have something valuable, in order to get something that is more important" (Longman 2009, p. 1447).

In the provided examples the authors of appreciation letters compliment volunteers and grant wholehearted approval and express deep admiration for their activity and enthusiasm. In these cases members of volunteer movement clearly understand that representatives would like to create goodwill. However, there are contexts in which one comes across compliments in disguise. Here a personal quality of a volunteer is highlighted as something that is worth mentioning, but the author of 
a thank-you letter does not directly refer to it: "I can hear children's reading skills improving and their confidence growing with each session".

It should be noted that the strategy of influencing the addressee is achieved with the help of the personal pronoun in the plural form " $w e$ " and the possessive pronoun "our". This means is also frequently used in letters of instruction, which volunteers receive while applying for taking part in this sphere of human activity. This technique - the tactic of consolidation - has the aim to heighten the sense of community and participation in the activity of great value. It serves the purpose of bringing together the addresser and the addressee, improving their relationship, allowing volunteers to feel part of "a big family". To prove this statement the following example may be provided: "You're such an important part of our organization".

Moreover, by using the lexical unit "part" the representative of a volunteer center emphasizes the fact that both members of the analyzed movement have the same interests and purposes, which contributes to establishing the sense of participation.

Analyzing texts of appreciation letters we pay attention to the fact that there are plenty of exclamation marks. This punctuation mark fulfills the expressive and intonational function of language showing a variety of strong feelings like surprise, anger or excitement. In the manual "Modern English Grammar: Morphology and Syntax" Professor O.V. Aleksandrova states that it "may be used to attract the attention of the reader to some idea, expressed in the narrative sentence" [Aleksandrova 2013, p. 176]. In the monograph Professor L.L. Baranova claims that the analyzed punctuation mark is used "after emotionally colored sentences" [Baranova 2008, p. 145]. Addressers use the exclamation mark not only in phrases to thank volunteers ("Thank you so much?"), but also in sentences where the significance of their work is highlighted ("This is such a staggering number and really shows what a giving community we have?').

To conclude, it is worth mentioning that the main communicative aim of the appreciation letter is to thank volunteers for their work and to express gratitude, which leads to cementing the relationship between representatives of volunteer centers and members of this sphere of people's activity. In order to achieve this aim a number of tactics are used. In present work the emotional tactics - the phatic tactic, the tactic of appreciation, that of compliment, of consolidation, of improving the relationship - have been analyzed.

Understanding communicative strategies and their linguistic manifestation in appreciation letters contributes to the retaining of skilled volunteers and to the more effective work of volunteer centers. The practical significance of the research lies in the fact that the results can be used in drafting this kind of business correspondence.

\section{List of factual materials}

Lingvisticheskii entsiklopedicheskii slovar' Lingvisticheskii entsiklopedicheskii slovar' [Linguistic encyclopedic dictionary]. Available at: http:// lingvisticheskiy-slovar.ru/description/kommunikatsiia/267 (accessed: 25.02.2018) [in Russian].

Longman 2009 - Dictionary of Contemporary English. Harlow: Pearson Education Limited, 2009, 1949 p. [in English].

Macmillan - Macmillan Dictionary for Advanced Learners. Macmillan Education. Available at: https:// www.macmillandictionary.com (accessed: 20.12.2018) [in English].

Oxford - Oxford Collocations Dictionary. Available at: oxfordlearnersdictionaries.com (accessed: 21.12.2018) [in English].

\section{References}

Aleksandrova 1984 - Aleksandrova O.V. Problemy ekspressivnogo sintaksisa [Problems of expressive syntax]. M.: Vysshaya shkola, 1984, 211 p. [in Russian].

Aleksandrova, Komova 2013 - Aleksandrova O.V., Komova T.A. Sovremennyi angliiskii yazyk: morfologiya $i$ sintaksis [Modern English Grammar: Morphology and Syntax]. M.: Izdatel'skii tsentr «Akademiya», 2013, 224 p. [in Russian].

Baranova 2008 - Baranova L.L. Ontologiya angliiskoi pis'mennoi rechi. Uchebno-metodicheskoe posobie $k$ kursu lektsii po orfoepii i orfografii sovremennogo angliiskogo yazyka. 2-e izd., dop. i pererab. [The ontology of English writing. Educational handbook to a course of lectures on orthoepy and orthography of modern English]. M.: Izdatel'stvo Pravoslavnogo Svyato-Tikhonovskogo Gumanitarnogo Universiteta, 2008, 312 p. [in Russian].

Zadornova 1986 - Zadornova V.Ya. Stilistika angliiskogo yazyka. Metodicheskie ukazaniya [Stylistics of the English language. Methodology instructions]. M.: Moskovskii universitet, 1986, 32 p. [in Russian].

Nazarova, Tolstova 2006 - Nazarova T.B., Tolstova T.V. Grammatika $v$ delovom obshchenii na angliiskom yazyke: ot funktsii $\mathrm{k}$ formam [Grammar in the registers of business English: from function to forms]. Vestnik Samarskogo gosudarstvennogo universiteta [Vestnik of Samara State University], 2006, no. 10/2(50), pp. 187-196. Available at: http://vestniksamgu.ssau.ru/gum/2006web10-2/yaz/ 17_Nazarova_Tolstova.pdf. [in Russian].

Saidgasanova 2015 - Saidgasanova E.U. Dokumenty volonterskogo obedineniya $v$ kommunikativnom aspekte (na materiale dokumentov Volonterskogo tsentra «Proryv» VolGU): dis. ... kand. filol. nauk [Documents of the volunteer association in the communicative aspect (on the material of the documents of the Volunteer Center "Proryv" in Volgograd State University): Candidate's of Philological Sciences thesis]. Volgograd, 2015, 182 p. [in Russian].

Sternin 2001 - Sternin I.A. Vvedenie $v$ rechevoe vozdeistvie [Introduction to speech influence]. Voronezh: Izdatel'stvo Voronezhskogo gosudarstvennogo universiteta, 2001. 178 p. [in Russian].

Akhmanova 1966 - Akhmanova O.S. Slovar' lingvisticheskikh terminov [Dictionary of linguistic terms]. M.: Sovetskaya entsiklopediya, 1966, 598 p. [in Russian]. 
Zhevachevskaya K.I.

Communicative strategies of appreciation letters sent to American volunteers and their linguistic manifestation

\section{Библиографический список}

Александрова 1984 - Александрова О.В. Проблемы экспрессивного синтаксиса. М.: Высшая школа, 1984. $211 \mathrm{c}$.

Александрова, Комова 2013 - Александрова О.В., Комова T.A. Современный английский язык: морфология и синтаксис. М.: Издательский центр «Академия», 2013. 224 с.

Баранова 2008 - Баранова Л.Л. Онтология английской письменной речи: учебно-метод. пособие к курсу лекций по орфоэпии и орфографии современного английского языка. 2-е изд., доп. и перераб. М.: Изд-во Православного Свято-Тихоновского гуманитарного университета, 2008. 312 с.

Задорнова 1986 - Задорнова В.Я. Стилистика английского языка: методические указания. М.: Московский университет, 1986. 32 с.
Назарова, Толстова 2006 - Назарова Т.Б., Толстова T.B. Грамматика в деловом общении на английском языке: от функции к формам // Вестник Самарского государственного университета. 2006. № 10/2 (50). C. 187-196. URL: http://vestniksamgu.ssau.ru/ gum/2006web10-2/yaz/17_Nazarova_Tolstova.pdf.

Саидгасанова 2015 - Саидгасанова Э.У. Документы волонтерского объединения в коммуникативном аспекте (на материале документов Волонтерского центра «Прорыв» ВолГУ): дис. ... канд. филол. наук. Волгоград, 2015. 182 с.

Стернин $2001-$ Стернин И.А. Введение в речевое воздействие. Воронеж: Издательство Воронежского государственного университета, 2001. $178 \mathrm{c}$.

Ахманова 1966 - Ахманова O.C. Словарь лингвистических терминов. М.: Советская энциклопедия, 1966. 598 с. 